\title{
IMPROVING READING SKILL OF PROCEDURE TEXT TROUGH PICTURE WALK
}

\author{
Ai Solihah', Ari Rustandi \\ ${ }^{1}$ IKIP Siliwangi \\ ${ }^{2}$ IKIP Siliwangi \\ ${ }^{1}$ Aisolihah47@gmail.com, ${ }^{2}$ Arirustandi94@yahoo.com
}

\begin{abstract}
This study has a purpose at improving the reading skill in the topic "Procedure Text" of the students through Picture Walk. This research was a classroom action research conducted in two cycles, consisting of plan, implementation, observation or evaluation and reflection. The subjects of this study were 30 students of class VII A SMP Putra Juang Cianjur. There were 14 boys and 16 girls. The result of data analysis of the mean score of the first cycle was 67. Meanwhile, the mean score of the second cycle was 94.3. From the data, it can be said that the result of learning reading skill in the material "Procedure text using picture walk" in cycle I to cycle II has improved by 27.3. Based on the results of data analysis and discussion it can be concluded that the result of learning Reading Skill in the material "Procedure Text using Picture Walk" can be improving Reading Skill on the students of class VII A SMP Putra Juang. It is recommended for English teachers to apply Reading skill using Picture Walk because it can improve the students' achievement on Reading skill.
\end{abstract}

Keywords: Reading, Procedure Text, Picture Walk

\section{INTRODUCTION}

In our lives, language is the most significant communication tool in communication. Communication can be done by speaking, writing and so on. The field of language study is a very important field of study. In line with the development of human science and technology, it is demanded to have good language skills, a person who has good language skills will more easily absorb and convey information both orally and in writing (Rediasih, 2017).

Language as a medium of information is imperative to master. One of the languages we must quasi is English. English has been introduced at playgroups, elementary school, junior high school, as of education in Indonesia that use in the workplace. Widely used for many people around the world to communicate with each other. English has a big contribution in accommodating many people to enrich their knowledge and skills in various fields, such as education, tourism, religion, technology, and the global economy. In Indonesia English is used as a foreign language. Most of the countries are including English as a compulsory lesson in the school. Harmer in (2001: 3) states that the reasons that many countries take English as a compulsory lesson are because of some factors like economics, travel, information exchange, and popular culture

English as an international language, which is often used in the world as a means of communication. In addition, English language skills are very important possessed by children who live in areas that have tourist attractions. Because, the English language skills of regional children are expected to introduce regional wealth to foreign tourists (Sutarsyah, 2017). The purpose of learning English in schools is to develop language skills both verbally and in writing. 
The intended English language skills are listening, speaking, reading, and writing skills. The four language skills are a unity that cannot be separated from one another but can only be distinguished. Reading is an activity informed by the apprehension of images, shapes, patterns, and rhythms, which come to be recognized through repeated encounters and remembered forms; the meanings that are made in reading are in excess of the meanings that arise from the interpretation of written language (Lorange, 2014: 30) as cited in Parmawati (2018). However reading as an interactive process. (Lems, Kristin., Leah D Miller., 2010) believe that reading is an activity involves an interactive process that connects the reader's background knowledge and their processing strategies to the text they read. Other experts as Celce-Murcia, Brinton, \& Snow, (2014) argues, "reading is an interactive sociocognitive process, involving a text, a reader, and a social context within which the reading activity takes place."

Thus, many people consider reading is just like other activities. People interpret reading from what they see through their eyes (Subekti, 2018). Some other people define reading as an interactive and sociocognitive process which relate the reader to the interactive and social context. According to Alderson (2000: 1) cited in Apsari \& Yana (2015), reading is to process text meaning through some process of interaction with print. When some peoples define reading as articulating words and as an interactive process, some experts also enrich reading the definition as an active and involved process. Reading is an active process what is proposed by (Stanovich, 1982) who state "reading is an active cognitive process that does indeed require using graphic (letter) and phonics (sounds) information, but for fluent readers particularly, the language-based cues-semantic (meaning) and semantic (grammar) seem far away more important than graphics and phonic cues". Besides, Grellet (2010) adds that reading is an active skill. Reading involves some strategies such as guessing, predicting, checking, and asking oneself questions. As a result, without these strategies, reading becomes very hard to do.

In reading, English learners in their school often learn some kinds of English texts graphics, namely narrative, recount, report, and procedure. Sometimes procedure text as one of the texts could be found by students outside the classroom. They can find procedure text when using a new gadget, sign up to social media, and even when making a cup of coffee. As (Knees \& Miller, 2006) define that procedure text is a piece of text type to explain how something can be done.Derewianka (2004) argues that procedure text is a kind of text designed to describe how something is achieved through a sequence of actions or steps. From the two statements above, the writer infers that procedure text is a kind of text that gives us instructions to do something through a sequence of actions or steps. Realizing the importance of procedure text, Indonesia government states the teaching of procedure text in some school levels such as junior high school. (Nasional, 2007)

Some of the junior high school students, however, have not reached the functional level well. They still have difficulties in the reading lesson. When the English teacher asked them to read a procedure text, only a few of them understood it. The result of their assignment of procedure text is not satisfactory. Some of them still have difficulties in knowing the idea of a process sequence. Use the medium or another strategy in teaching reading may be an alternative to make the student more understand the procedure text

Some of the junior high school students, however, have not reached the functional level well. They still have difficulties in the reading lesson. When the English teacher asked them to read a procedure text, only a few of them understood it. The result of their assignment of procedure text is not satisfactory. Some of them still have difficulties in knowing the idea of a process 
sequence. Use the medium or another strategy in teaching reading may be an alternative to make the student more understand the procedure text.

\section{METHOD}

This research was conducted at Putra Juang Middle School at Jl. Cipetir, Sukatani, Kec. Haurwangi, Kab. Cianjur, West Java. This class action research was conducted in the even semester of class VII A of Putra Juang Middle School in the 2018/2019 school year. This research was conducted in two cycles, each of which was only 1 meeting. Cycle I was held on Thursday 10 January 2019, while cycle II was on Thursday 17 January 2019. The subjects in this study were students of class VII A, amounting to 30 people. This class was chosen as the subject of research based on the results of preliminary observations, which showed that student reading was still low.

In implementing this class action the variables investigated are as follows: a) Input variables: Grade VII A students of Putra Juang Junior High School totaling 30 people, b) Process variables: Using Picture work strategies, c) Output variables: Increasing students' reading comprehension. This study uses a class action research design. Classroom action research is research conducted by a teacher in the classroom by performing specific actions the problemsolving. The problem that is being faced by the teacher in learning. There are three words in CAR, classroom, action, and research.

Research is an activity to investigate an object using certain methodology to gain data or information which is beneficial to improve the quality of anything, interested by researchers and important. Action is a planned activity to gain certain goal. Classroom defined as a group of students at certain time and certain teaching from similar teacher. Classroom here defined not only room space but defined as a group of students in the learning process (Arikunto \& Jabar, 2004) in journal (Mahmudi, 2011). This research is called classroom action research because this type of research offers a way and procedure to improve and improve the quality of learning in the classroom. In this study, researchers offer the application of Picture work to improve students' mastery of Reading.

Generally known five designs of CAR based on the founder: Kurt Lewin model, John Elliot Model, David Hopkins model, Mc Kernan model, and Kemmis \& Taggart model at journal of(McTAGGART, 1994) and in journal (Widayati, 2014). In Indonesian case,generally use Kemmis \& Taggart model, as it is the development from the basic concept of Action Research introduced by Kurt Lewin. Kemmis and Taggart's model is a string of integrated four components: plan, action, observe, and reflection which is united in one cycle. 


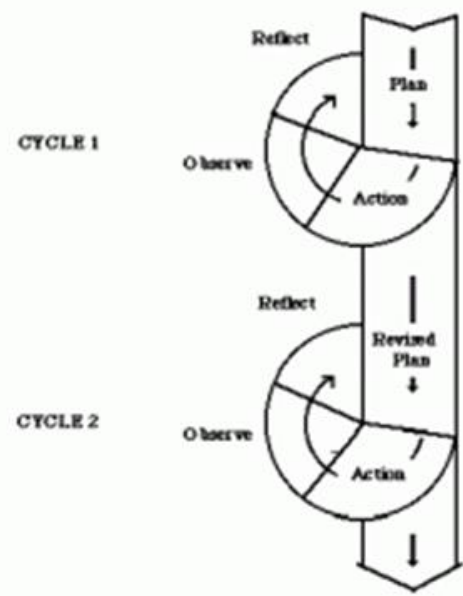

Graph 1. Kemmis \& Taggart CAR Cycles

(Source : Kusumah \& Dwitagama. 2009)

Data collection procedures performed in this study are as follows:1) Observation is done by observing the research subject. Through observation the data obtained in the form of qualitative data about how much this strategy can affect student activities and whether the learning activities carried out in accordance with the plan. 2) The test is used to measure the increase in students' ability in reading skill. This research uses pre-test and post-test. The pre-test is given at the pre-cycle stage before the strategy is applied and post-test is given at the end of each cycle. 3) Giving questionnaires, the purpose of giving questionnaires conducted in this study is to determine student responses regarding learning using the strategies implemented. 4) The purpose of the interview conducted in this study was to determine the observer's response regarding learning using the strategies implemented, where the input from the observer will be used as teacher reflection material.

The instruments used included observation sheets, questionnaire guidelines, and evaluation sheets. Observations were made by the teacher and observer, which aims to determine the habits and activities of students during the learning and teaching process. Questionnaires are used to determine students' responses to the actions given. Evaluation sheets are given after the strategy is applied. Evaluation is carried out to find out the development of students' reading mastery ability with the strategies implemented. Evaluation form sheets provided are in the form of reading tests. Analysis of the data used in this research is descriptive qualitative analysis and quantitative descriptive.

\section{RESULTS AND DISCUSSION}

\section{Results}

This research was carried out on Thursday 10 January 2019 at 10.00-11.20 West Indonesia Time and Tuesday 17 January 2019 at 07.00-08.20 West Indonesia Time, in class VII A of Putra Juang Middle School in 2018/2019, amounting to 30 students, 14 sons, and 16 daughters. a. Preliminary Observation Research Results

Student pretest scores at the pre-cycle stage are shown in the following table 1:

Tabel 1. Student learning outcomes data related to mastery of reading on the material Procedure text in the pre-cycle stage 


\begin{tabular}{llll}
\hline Score & Total & Persentase & Score KKM \\
\hline Total students grades $\geq 70$ & 12 & 40 & 70 \\
\hline Total students grades $\leq 70$ & 18 & 60 & \\
\hline Max & & 90 & \\
\hline Min & & 15 &
\end{tabular}

Based on Table 4.1 it can be explained that out of 30 Class VII A3 students who completed or reached KKM as many as 12 students or only 40\%, while those who had not reached KKM were 18 students or $60 \%$. At this stage, the highest score obtained by the participant is 90 , and the lowest score is 15 . Thus it can be concluded that student learning outcomes in understanding the topic of Procedure text are still shallow.

Based on the above data it can be concluded that the average value of student learning outcomes in mastery of reading on material Procedure text classically has not yet reached graduation. Teachers still apply conventional models in the learning process, where most are still focused on the teacher or what is often called the Teacher Learning Center. This, of course, makes student involvement in the learning process low which results in student inactivity in the teaching and learning process. Teachers need to increase student activity in the learning process by using more innovative learning models. For this reason, in this study, the authors used Reading Picture Work in Procedure text to increase reading interest.

b. $\quad$ Cycle I Research Results

Based on the analysis of learning outcomes data in cycle I of the Procedure text material, the data obtained are as in Table 2.

\begin{tabular}{llll}
\hline Score & Total & Persentase & Score KKM \\
\hline Total students grades $\geq 70$ & 18 & 60 & 70 \\
\hline Total students grades $\leq 70$ & 12 & 40 & \\
\hline Max & & 100 & \\
\hline Min & & 30 &
\end{tabular}

Based on the table above seen an increase in learning outcomes, for the average value increased from 46.6 in pre-cycle to 67 with $60 \%$ completeness learning increased from pre-cycle $40 \%$. In this cycle, the highest value obtained by participants is 100 , and the lowest value is 30 .

Based on these results, it can be seen that the mastery of students' reading has increased in the number of students who have completed under the KKM score $\geq 70$ and the average value classically. However, in this cycle, the level of completeness of students has not met the standard completeness criteria. For this reason, the next step is summarized in cycle II.

c. Cycle II Research Results

Based on the analysis of learning outcomes data in cycle II with Procedure Text material, it can be grouped into the completeness category of student learning outcomes as in Table 3.

Table 3. Student learning outcomes data related to mastery of reading on Things Around Us material in the second cycle stage

\begin{tabular}{llll}
\hline Score & Total & Persentase & Score KKM
\end{tabular}




\begin{tabular}{llll}
\hline Total students grades $\geq 70$ & 29 & 96,8 & 70 \\
\hline Total students grades $\leq 70$ & 1 & 3,2 & \\
\hline Max & & 100 & \\
\hline Min & 60 & 94,3
\end{tabular}

The table above shows the average value of the class rose 94.3 from the first cycle 67 , and mastery learning from $60 \%$ in the first cycle increased by $96.8 \%$ in the second cycle. In this cycle, the highest value obtained by participants is 100, and the lowest value is 60 .

Based on the above data it can be concluded that the average learning outcomes in students' mastery of reading is 94.3 and has reached the graduation criteria classically that is an average value of $\geq 70$ following KKM scores and in this cycle students who complete by KKM scores have reached $96.8 \%$.

\section{Discussion}

Overall, research on the application of contextual teaching and learning picture walk models in teaching reading comprehension of seventh-grade students of SMP 165 Putra Juang provides positive results in the form of an increase in students' ability to read comprehension. This is based on the results obtained from two cycles of action implementation. The implementation of several cycles is a certain stage by implementing a learning plan that has been compiled based on the picture walk model.

In the implementation of this cycle II action, students preview the images or graphic features in fiction or nonfiction texts to make predictions, and activate background or prior knowledge to enhance comprehension, so as to stimulate and inspire students' potential optimally in determining the main points of thought in reading that ultimately can improve students' ability to read comprehension.

With the inclusion of images that are in accordance with the text, learning feels more varied so that it is not boring for students and students to become more interested in learning, but also to overcome verbalism in relation to the content of the discourse so that it can increase students' insight, especially for other subjects. Based on the test results in this second cycle, most students have been able tofind the main points of thought in the reading. Based on the test results in the second cycle there is a significant increase in value so that the author is considered enough of this research until the second cycle.

The Student responses to the application of Reading Picture walk to improve students' mastery of reading showed a positive response with the acquisition of an average student response of 27.6. It means that students agree with the application of the Reading Picture Walk that can improve the reading comprehension of Grade VII A students at Putra Juang Middle School.

\section{CONCLUSION}

The results of the study prove that students' ability to read comprehension after the learning is carried out by applying the picture walk model has a significant improvement. Based on the results of pretest the highest score obtained by the participant is 90 , and the lowest score is 15 . Thus it can be concluded that student learning outcomes in understanding the text are still shallow. In this cycle I, the highest value obtained by participants is 100 , and the lowest value is 30 . Based on these results, it can be seen that the mastery of students' reading has increased. In cycle II the highest value obtained by participants is 100 , and the lowest value is 60 . Based on the results of the data analysis and discussion above it can be concluded that the mastery of 
reading in VII A grade students at Putra Juang Middle School increased by using the Reading Picture Walk.

\section{ACKNOWLEDGMENTS}

Thank you very much to Mrs. Aseptiana Parmawati, M.Pd, Ms. Yanuarti Apsari, M.Pd the Mr. Restu, Trisnendi Syahrizal, M.Hum, Dr. Irma Savitri Sadikin, M.Pd who helped me in completing my journal assignments, to my parents Mr. Inda and Ms. Uti and my brothers Dadang, M.Pd, Ali Wardana, S.Pd, not forgetting the best wishes and prayers to Allah SWT for giving me the opportunity and strength to complete it.

\section{REFERENCES}

Apsari, Y., \& Yana, Y. (2015). Teachers'techniques And Problems In Teaching Reading. Jurnal Ilmiah P2M STKIP Siliwangi, 2(2), 217-233.

Arikunto, S., \& Jabar, C. S. A. (2004). Evaluasi program pendidikan. Jakarta: Bumi Aksara, $1-2$.

Celce-Murcia, M., Brinton, D., \& Snow, M. A. (2014). Teaching English as a second or foreign language. (2008), 706.

Derewianka, B. (2004). Exploring How Texts Work. In Exploring How Texts Work. Sydney.

Knees, S., \& Miller, T. (2006). The role of actigraphy. The Plantsman, (September).

Lems, Kristin., Leah D Miller., \& T. M. S. (2010). Teaching Reading to English Language Learner. In New York: The Guilford Press.

Mahmudi, I. (2011). CIPP: Suatu Model Evaluasi Program Pendidikan. Jurnal At-Ta'dib, 6(1), $112-124$.

McTAGGART, R. (1994). Participatory Action Research: Issues in theory and practice. Educational Action Research, 2(3), 313-337. https://doi.org/10.1080/0965079940020302

Nasional, D. P. (2007). Statuta Universitas Andalas.

Parmawati, A. (2018). The Study Correlation Between Reading Habit And Pronunciation Ability At The Second Grade Students Of Ikip Siliwangi. Eltin Journal, Journal Of English Language Teaching In Indonesia, 6(1), 46-52.

Rediasih, L. (2017). Pengaruh Model Pembelajaran Debate Terhadap Keterampilan Berbicara Pada Mata Pelajaran Bahasa Indonesia Siswa Kelas V.

Stanovich, K. E. (1982). Individual differences in the cognitive processes of reading: II. Textlevel processes. Journal of Learning Disabilities, 15(9), 549-554.

Subekti. (2018). The Influence Of English Writing Skill Toward Writing Achievement. International Affairs. https://doi.org/10.2307/2602098

Sutarsyah, C. (2017). Pembelajaran Bahasa Inggris sebagai Muatan Lokal pada Sekolah Dasar di Propinsi Lampung . AKSARA Jurnal Bahasa Dan Sastra, 18, 35-43.

Widayati, A. (2014). Penelitian Tindakan Kelas. Jurnal Pendidikan Akuntansi Indonesia, 6(1). https://doi.org/10.21831/jpai.v6i1.1793 